Indo. J. Chem. Res., 2019, 6(2), 101-106

\title{
ISOLASI MIKROBA DARI AIR ASAM TAMBANG PADA AREA PERTAMBANGAN TEMBAGA DI PULAU WETAR, PROVINSI MALUKU
}

\section{Isolation of Microbes from Mine Acid Water on Copper Mine Area in Wetar Island, Maluku Province}

\author{
Yusthinus T. Male ${ }^{1 * *}$, Deddy W.S. Modok ${ }^{1}$, Cecilia A. Seumahu ${ }^{2}$, Dominggus Malle \\ ${ }^{1}$ Department of Chemistry, Faculty of Mathematics and Natural Sciences \\ Pattimura University, Kampus Poka, Jl. Ir. M. Putuhena, Ambon 97134 \\ ${ }^{2}$ Department of Biology, Faculty of Mathematics and Natural Sciences \\ Pattimura University, Kampus Poka, Jl. Ir. M. Putuhena, Ambon 97134 \\ ${ }^{3}$ Department of Animal Husbandry, Faculty of Agriculture \\ Pattimura University, Kampus Poka, Jl. Ir. M. Putuhena, Ambon 97134 \\ *Corresponding author, e-mail: yusmale@fmipa.unpatti.ac.id
}

Received: Dec. 2018 Published: Jan. 2019

\begin{abstract}
This research was conducted to find bacteria from the genus Acidithiobacillus which isolated from mine acid water in the copper mining area on Wetar Island, Maluku Province. This bacterium will be utilized in the biohidrometallurgical process (bioleaching) for copper extraction in mining area. The results of this study indicate that bacteria can be isolated from mine acid water samples by enrichment method that was use liquid media from Leathen which is optimized using Trypton Soya Broth (TSB) and bacterial growth on solid media. The presence of Thiobacillus sp bacteria was confirmed by the results of gene analysis using a 16S rRNA sequence showing the presence of mixed bacterial colonies but not a single colony.
\end{abstract}

Keywords: Bacteria, acid mine water, Thiobacillus sp., copper,bioleaching, Wetar Island.

\section{PENDAHULUAN}

Indonesia dikenal memiliki potensi sumberdaya tambang yang besar dengan beragam jenis bahan tambang yang tersebar dari Sabang Sampai Merauke. Kawasan Timur Indonesia, khususnya Papua dan Kepulauan Maluku banyak mengandung deposit tembaga yang potensial. Untuk Propinsi Maluku, deposit terbesar terdapat di Pulau Wetar, Kab. Maluku Barat Daya.

Dewasa ini, tantangan investasi di sektor pertambangan semakin berat untuk daerahdaerah yang memiliki cadangan tembaga yang relatif kecil. Investor tidak tertarik karena menghadapi banyak kendala, diantaranya nilai keekonomian cadangan, ketidak-jelasan pengaturan kewenangan penanganan sumberdaya mineral di era otonomi daerah, diperlukan peralatan yang kapasitasnya besar sehingga memerlukan modal yang besar pula (Sudarsono, 2003). Mencermati hal di atas, diperlukan terobosan teknologi pertambangan, khususnya eksplorasi tembaga sehingga deposit tembaga yang relatif kecil di daerah dapat di dimanfaatkan secara optimal dan berkelanjutan oleh perusahaan lokal, dengan memperhatikan lingkungan sosial, fisik dan biologi.

Telah lama diketahui bahwa mikroorganisme berperan dalam pelarutan logam sulfida, tatapi baru pada tahun 1947, Colmer dan Hinkle berhasil mengisolasi bakteri genus Acidithiobacillus ferrooxidans dan Thiobacillus thiooxidans dari air tambang asam. Sejak periode 1950-1980, teknologi biohidrometalurgi atau bioleaching telah dijadikan pilihan utama untuk pemisahan tembaga dan logam lainnya dari pembuangan (damps) atau dari mineral berkadar rendah. Jika dilihat, proyek biohidrometalurgi besar yang sukses justru berada di negara-negara berkembang. Hal ini dimungkinkan karena selain negara-negara berkembang banyak memiliki cadangan mineral, teknologi biohidrometalurgi cocok dikembangkan karena mudah serta biayanya ringan (Acevedo, 2002).

Bioleaching merupakan suatu proses untuk melepaskan atau mengekstraksi logam dari mineral atau sedimen dengan bantuan organisme hidup atau untuk mengubah mineral sulfida 
sukar larut menjadi bentuk yang larut dalam air dengan memanfaatkan mikroorganisme. Bioleaching menyebabkan proses asidifikasi dan kelarutan logam berat, sehingga proses bioleaching menjadi metode yang menjanjikan untuk menghilangkan logam berat dari sedimen atau lingkungan terkontaminsasi (Chen and Lin, 2001. Bakteri Acidithiobacillus ferrooxidans memiliki kemampuan untuk melarutkan logam berat dan telah lama digunakan pada proses bioleaching tembaga dan emas. Selain itu bakteri A. ferrooxidans mampu melarutkan sulfide logam (MS) menjadi ion sulfat $\left(\mathrm{SO}_{4}{ }^{2-}\right)$ dan ion logam senyawa logam sulfat $\left(\mathrm{MSO}_{4}\right)$. Dari proses tersebut logam dapat dipisahkan dan diperoleh kembali secara bioleaching (Pradhan et al., 2008).

Pada penelitian ini, akan dilakukan studi jenis koloni/genus dari mikroba yang secara alamiah terdapat pada area penambangan, kolam bekas tambang (cair) serta limbah padat (tailing) tembaga untuk menemukan bakteri turunan (strain) Acidithiobacillus) ferrooxidans isolat lokal. Lokasi pengambilan sampel adalah area penambangan PT. Batutua Tembaga Raya, di Pulau Wetar, Kab. Maluku Barat Daya, Provinsi Maluku. Isolat lokal digunakan karena diduga bahwa genus Acidithiobacillus ferrooxidans isolat lokal telah mengalami mutasi dan adaptasi sehingga lebih sesuai untuk daerah tambang tersebut.

Media yang digunakan dalam isolasi ini adalah media cair dari Leathen et al. (1956) dalam Putro (2008), karena media ini merupakan media yang paling optimum untuk menumbuhkan bakteri Thiobacillus sp. Hal ini terjadi karena kandungan besi $\mathrm{Fe}^{2+} \rightarrow \mathrm{Fe}^{3+}$ pada media ini optimal ( $1 \mathrm{~g}$ per liter). Keadaan inilah diduga menyebabkan isolat-isolat bakteri lebih mampu menyesuaikan diri pada media tumbuh tersebut. Media Leathen ini digunakan karena lebih mudah menekan terjadinya oksidasi besi secara kimia karena semakin tinggi kandungan besi ferronya maka kemungkinan terjadinya oksidasi secara kimia juga semakin besar (Nurseha, 2000).

\section{METODE PENELITIAN}

\section{Waktu dan Tempat Penelitian}

Pengambilan sampel dilakukan pada delapan) titik sampel (kode sampel: A1, A2,A3, B1,B2,B3, C1dan C2) pada areal processing heap leach pertambangan tembaga Lurang Kecamatan Wetar Utara (Gambar 1). Proses isolasi dan identifikasi dilakukan di Laboratorium Mikrobiologi Jurusan Biologi FMIPA Universitas Pattimura Ambon.

\section{Bahan}

Bahan-bahan yang digunakan adalah: Sampel Air asam tambang, Alkohol 95\%, spirtus, kapas, akuades, $\mathrm{FeSO}_{4} \cdot 7 \mathrm{H}_{2} \mathrm{O}$ (E. Merck), $\left(\mathrm{NH}_{4}\right)_{2} \mathrm{SO}_{4}$ (E. Merck), $\mathrm{K}_{2} \mathrm{HPO}_{4}(E . \quad$ Merck), $\mathrm{MgSO}_{4} \cdot 7 \mathrm{H}_{2} \mathrm{O}$ (E. Merck), $\mathrm{KCl}$ (E. Merck), $\mathrm{Ca}\left(\mathrm{NO}_{3}\right)_{2}$ (E. Merck), Agar 2\% dan Tryptone Soya Broth (TSB).

\section{Alat}

Alat-alat yang digunakan adalah: Alat-alat gelas (pyrex), spatula, botol sampel polietilen, Autoklaf (TOMY ES-215), Inkubator Shaker (SHEL LAB), Bunsen, Hot plate (cimarec 2), timbangan analitik (Adventure Pro, OHAUS), LAF (Laminar Air Flow) (Lab Culture class II Type B ESCO), GPS (Global Positioning System), dan Sekuensi 16S rRNA.

\section{Penyiapan media}

Pada penelitian ini digunakan media cair $9 \mathrm{~K}$ dari Leathen dkk. (1956) dalam Putro (2008) dengan $\mathrm{pH}$ 3,5. Komposisi media disajikan pada Tabel 1 .

Semua bahan tersebut dicampurkan ke dalam $800 \mathrm{~mL}$ akuades kecuali $\mathrm{FeSO}_{4} \cdot 7 \mathrm{H}_{2} \mathrm{O}$, diaduk dan disterilkan pada suhu $121^{\circ} \mathrm{C}$ kemudian didinginkan. Untuk $\mathrm{FeSO}_{4} .7 \mathrm{H}_{2} \mathrm{O}$, dipersiapkan akuades yang telah steril dan telah ditetapkan pHnya, yaitu pH 3,5, sebanyak 200 $\mathrm{mL}$, setelah itu dimasukkan $\mathrm{FeSO}_{4} \cdot 7 \mathrm{H}_{2} \mathrm{O}$ dan dipanaskan sampai suhu $50^{\circ} \mathrm{C}$, lalu didinginkan. Kedua larutan dicampur secara aseptik. Media kemudian dibagi-bagi ke dalam tabung isolasi yang telah disterilkan. 
Yusthinus T. Male dkk. / Indo. J. Chem. Res., 2019, 6(2), 101-106

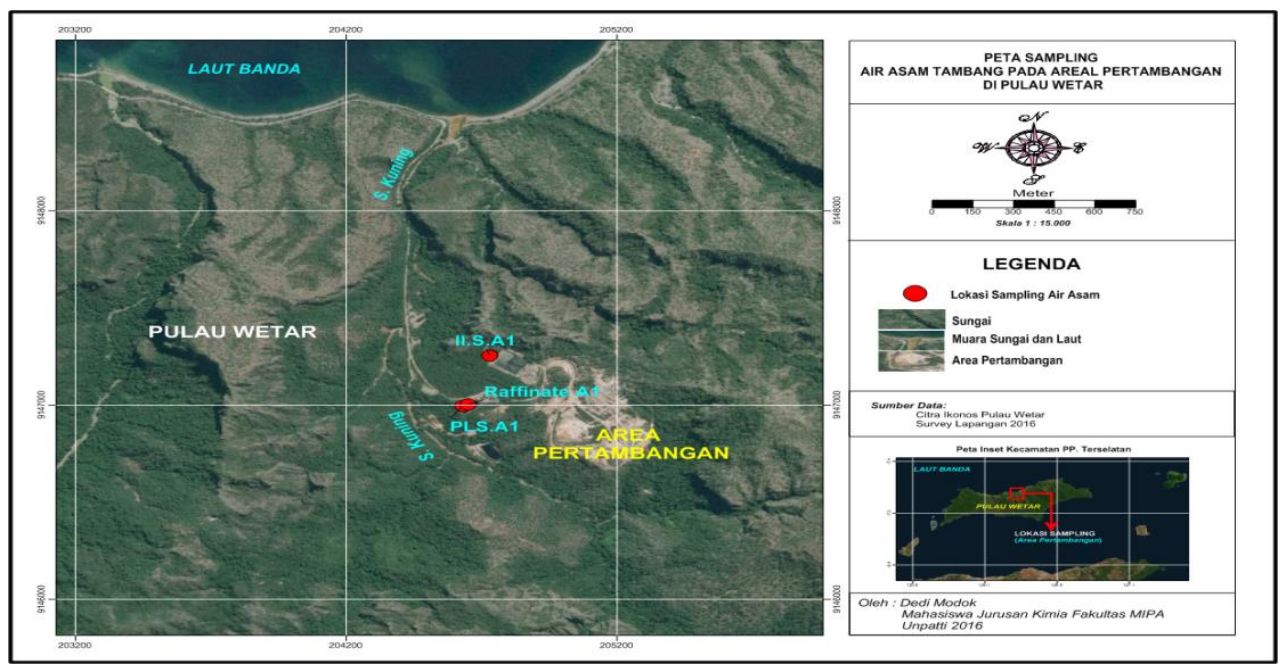

Gambar 1. Peta pulau Wetar dan lokasi pengambilan sampel

\section{Isolasi bakteri dari air asam tambang}

Isolasi mikroba/bakteri dilakukan dengan cara memasukkan $10 \mathrm{~mL}$ sampel Air Asam ke dalam media steril yang langsung diinkubasi. Medium isolasi yang digunakan berupa medium cair yang selektif untuk pertumbuhan bakteri, yaitu media 9K. Media tersebut kemudian diinkubasi pada suhu kamar dengan cara dikocok dengan menggunakan shaker $250 \mathrm{rpm}$, selanjutnya disimpan pada ruangan yang tidak terlalu banyak cahaya. Apabila telah terjadi perubahan warna menjadi kuning atau kuning karat, maka di dalam sumber tersebut diduga terdapat Thiobacillus sp.

Tabel 1. Komposisi Medium Cair (tiap 800 ml)

\begin{tabular}{cc}
\hline Bahan & Medium $\boldsymbol{T}$. ferrooxidans $(\mathbf{9 K})$ \\
\hline $\mathrm{K}_{2} \mathrm{HPO}_{4}$ & 0,15 gram \\
$\left(\mathrm{NH}_{4}\right)_{2} \mathrm{SO}_{4}$ & 0,01 gram \\
$\mathrm{Ca}\left(\mathrm{NO}_{3}\right)_{2}$ & 0,01 gram \\
$\mathrm{MgSO}_{4} \cdot 7 \mathrm{H}_{2} \mathrm{O}$ & 0,50 gram \\
$\mathrm{KCl}$ & 0.05 gram \\
$\mathrm{FeSO}_{4} \cdot 7 \mathrm{H}_{2} \mathrm{O}$ & 1,00 gram
\end{tabular}

Sumber: (Nurseha, 2000 dalam Putro, 2008)

\section{Karakterisasi bakteri Thiobacillus sp.}

Setelah isolat diperoleh maka perlu dilakukan pemindahan isolat dari media cair ke media padat yang selektif. Pemindahan isolat dari media cair ke media padat dilakukan dengan cara memasukkan media agar yang telah dipersiapkan sebanyak $10 \mathrm{~mL}$ ke dalam cawan petri yang sudah steril. Isolat pada medium cair tersebut kemudian disebar sebanyak $200 \mu \mathrm{m}$ ke atas media padat yang telah disiapkan, kemudian diinkubasi sampai terbentuk koloni dari bakteri yang diinginkan. Pengamatan mikroskopis dengan menggunakan mikroskop dilakukan setelah koloni terbentuk, kemudian dianalisis untuk mengetahui morfologi dan sifat-sifat yang melekat pada bakteri tersebut. Komposisi media agar (padat) disajikan pada Tabel 2.

Tabel 2. Komposisi Media Padat (agar) tiap $800 \mathrm{~mL}$

\begin{tabular}{cc}
\hline Bahan & $\begin{array}{c}\text { Medium } \mathbf{T} . \\
\text { ferrooxidans (9K) }\end{array}$ \\
\hline $\mathrm{K}_{2} \mathrm{HPO}_{4}$ & $0,15 \mathrm{~g}$ \\
$\left(\mathrm{NH}_{4}\right)_{2} \mathrm{SO}_{4}$ & $0,01 \mathrm{~g}$ \\
$\mathrm{Ca}\left(\mathrm{NO}_{3}\right)_{2}$. & $0,01 \mathrm{~g}$ \\
$\mathrm{MgSO}_{4} .7 \mathrm{H}_{2} \mathrm{O}$ & $0,50 \mathrm{~g}$ \\
$\mathrm{KCl}$ & $0.05 \mathrm{~g}$ \\
$\mathrm{FeSO}$ & $1,00 \mathrm{~g}$ \\
$\mathrm{Agar}_{2} \mathrm{O}$ & $12,00 \mathrm{~g}$ \\
Sumber : Leathen dkk. (1956) dalam Putro \\
(2008)
\end{tabular}

Isolat yang sudah tumbuh pada media padat ini kemudian dapat dipergunakan selain untuk pemurnian isolat pada medium yang sama juga digunakan untuk pewarnaan gram diferensial. Pewarnaan gram diferensial bertujuan untuk melihat bakteri secara mikroskopik dengan bantuan mikroskop untuk membedakan antara bakteri gram positif dengan bakteri gram negatif. Karakterisasi dari bakteri yang telah didapatkan, dilakukan setelah mendapatkan hasil dari pewarnaan gram diferensial tersebut. Selanjutnya identifikasi dilakukan di PT. Genetika Sains 
Jakarta dengan menggunakan sekuensi gen $16 \mathrm{~s}$ rRNA.

\section{HASIL PENELITIAN}

\section{Isolasi Bakteri dari Air Asam Tambang}

Isolasi bakteri dilakukan pada delapan sampel air asam dari tiga lokasi yang berbeda dengan perlakuan yang sama yaitu menumbuhkan mikroba Thiobacillus sp. Dari kedelapan sampel, terlihat bahwa sampel $A_{1}, A_{2}$, dan $A_{3}$ memiliki hasil yang lebih bagus. Hal ini ditandai dengan berubahnya warna media cair tersebut dari warna hijau muda menjadi kuning keruh yang menandakan keberadaan bakteri Thiobacillus sp. (Putro, 2008). Hasil ini sesuai dengan lokasi pengambilan sampel A tepat di lokasi Intermediet Leach Solution (ILS). Dari ketiga sampel tersebut kemudian dipilih sampel $\mathrm{A}_{1}$ yang menunjukkan pertumbuhan yang paling bagus, namun setelah dilakukan penyebaran media cair diatas media padat ternyata hasilnya tidak begitu baik dikarenakan media cair ini mengandung sedikit bahan organik sebagai nutrisi dan oksigen agar berlangsungnya reaksi aerob.

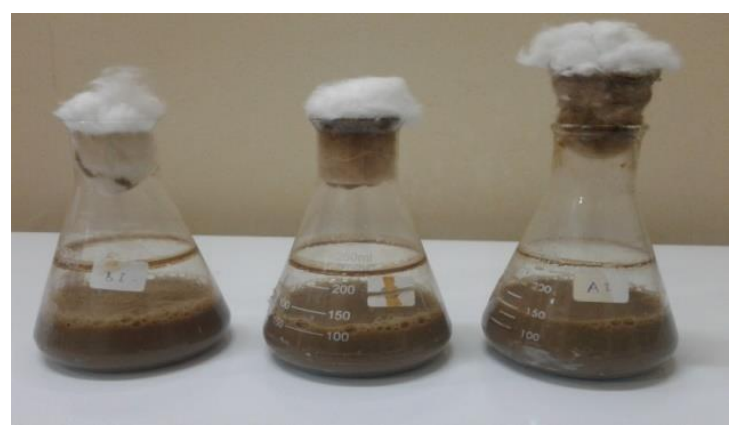

Gambar 2. Hasil inkubasi sampel A pada media padat

Thiobacillus tergolong bakteri kemoautotrof, yang mana proses metabolisme bakteri ini memanfaatkan energi dari reaksi kimia untuk membuat makanan sendiri dari bahan organik dan juga menggunakan bahan kimia dari oksidasi molekul organik untuk menyusun makanannya, perlu dilakukan modifikasi pada media cair untuk mendapatkan hasil yang lebih baik. Pada proses modifikasi media cair, disiapkan media cair yang baru dengan komposisi yang sama kemudian ditambah Trypton Soya Broth (TSB) sebagai penyedia asam amino dan substansi nitrogen lainnya sebagai penambah nutrisi pada media untuk pertumbuhan mikroba. Hasil inkubasi dari sampel tersebut dapat dilihat pada Gambar 2.

Isolat-isolat bakteri pada media cair kemudian dipipet $200 \mu \mathrm{L}$ di atas media padat yang komposisinya sama dengan media cair, namun ada penambahan agar sebanyak $2 \%$ kemudian diinkubasi sampai terbentuk koloni dari bakteri yang diinginkan.Hasil penumbuhan isolat bakteri dari media cair ke media padat dapat dilihat pada Gambar 3.

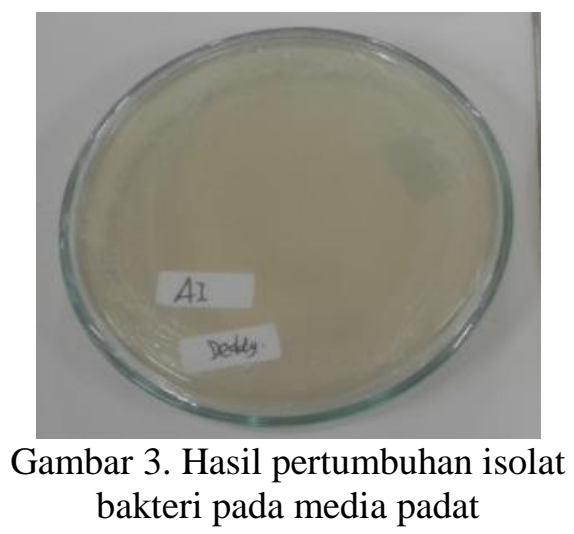

Isolat bakteri yang dapat tumbuh pada media cair belum tentu dapat tumbuh pada media padat, dalam hal ini media agar. Bakteri yang diisolasi adalah bakteri asidofi yang membutuhkan senyawa anorganik untuk pertumbuhan dan perbanyakan, bukan pada senyawa organik seperti agar (Nurseha, 2000).

\section{Analisis gen 16S rRNA}

Hasil inkubasi media padat menunjukkan ada koloni yang diduga adanya pertumbuhan bakteri. Hasil ini kemudian digores dan dicampurkan dengan garam fisiologi dan disentrifuge agar campuran homogen. Campuran homogen tersebut dipipet ke dalam FTA Card dan dianalisis untuk mencari identitas koloni bakteri. Hasil analisis gen menggunakan sekuensi 16S rRNA dapat dilihat pada Gambar 4.

Hasil analisis gen 16S rRNA mununjukan bahwa koloni bakteri bukan berasal dari koloni tunggal. Pada penelitian ini dilakukan metode isolasi bakteri dengan cara pengayaan bakteri yang umumnya cocok untuk sampel air asam. Bakteri Thiobacillus kebanyakan terdapat pada 
sedimen yang bisa dilakukan dengan metode tidak langsung, sedangkan untuk memperoleh Thiobacillus yang terdapat dalam air asam dapat dilakukan isolasi secara langsung ditempat, yaitu metode pengisolasian mikroorganisme secara langsung dari sampel dengan proses pengayaan terlebih dahulu. Isolasi tersebut dapat didahului dengan pengenceran atau tidak. Metode tidak langsung adalah metode yang dilakukan untuk meningkatkan jumlah mikroorganisme yang diinginkan sehingga menjadi lebih banyak daripada mikroorganisme lainnya dalam inokulum asli (Casida, 2001).

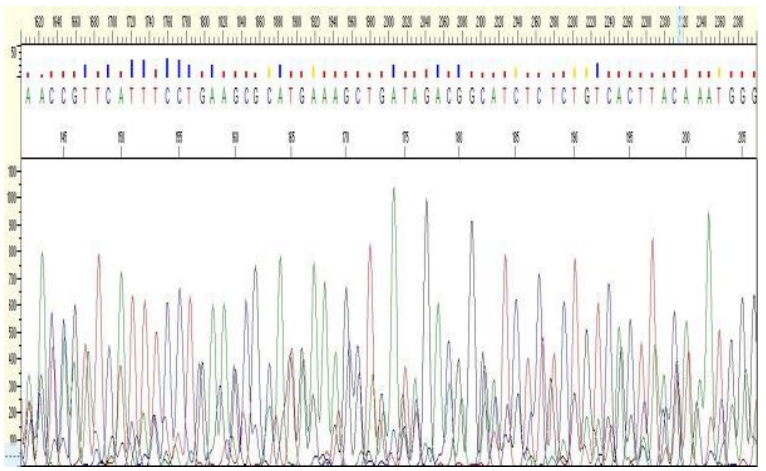

Gambar 4. Hasil sekuensi

Dari hasil analisis gen 16S rRNA menunjukkan bahwa koloni yang diperoleh masih berupa koloni campuran dan bukan berasal dari koloni tunggal. Terbentuknya koloni bakteri merupakan tanda bahwa bakteri mampu hidup pada media padat tersebut dengan ciri-ciri membentuk koloni karat di permukaan media, berlendir dan mencembung di permukaan media agar.

Pada penelitian ini, sampel yang dianalisis menggunakan sekuensi gen 16S rRNA tidak dapat dilanjutkan untuk mendapatkan koloni tunggal. Hal ini karena bakteri yang terdapat dalam sampel tersebut tidak dikultur untuk waktu yang lama. Dengan demikian jumlah nutrisi yang tersedia tidak lagi dapat mendukung pertumbuhan bakteri ataupun karena akumulasi produk samping metabolisme yang bersifat toksik. Pada kondisi ini laju kematian bakteri lebih besar dari pada laju pertumbuhan bakteri sehingga jumlah populasi bakteri jauh menurun (Kamil, 2008).

\section{KESIMPULAN}

Berdasarkan hasil penelitian yang telah dilakukan dapat disimpulkan bahwa bakteri Thiobacillus sp. dapat diisolasi dari sampel air asam tambang dengan metode pengayaan yaitu menggunakan media cair dari Leathen yang dioptimalkan menggunakan Trypton Soya Broth (TSB) dan dilakukan penumbuhan bakteri pada media padat. Keberadaan bakteri Thiobacillus sp. dipastikan dengan hasil analisis gen menggunakan sekuensi 16S rRNA yang menunjukkan ada aktifitas koloni bakteri campuran dan bukan merupakan koloni tunggal.

\section{UCAPAN TERIMA KASIH}

Terima kasih kepada Lembaga Penelitian dan Pengabdian Kepada Masyarakat (LP2M) Universitas Pattimura yang telah membiayai penelitian ini melalui kegiatan Penelitian Produk Unggulan Daerah Tahun 2017 dengan nomor kontrak: $\quad$ 08.74.2H/SPK-PJ/UN13-PPBJ/PUDLP2M/2017

\section{DAFTAR PUSTAKA}

Acevedo, F., 2002, Present and Future of Bioleaching in Developing Countries, Electronic Journal of Biotechnology, 5(2), 196-199.

Casida J.L.E., 2001, Industrial Microbiology, New Age Int. Ltd. Pub. New Delhi.

Chen, S-Y, Lin, J-G., 2001, Bioleaching of Heavy Metals from Sediment: Significance of $\mathrm{pH}$, Chemosphere, 44(5), 1093-1102.

Kamil, I., 2008, Pemanfaatan Bakteri Thiobacillus thioparus untuk Mendegradasi Kandungan Sulfur dalam Gas Alam., Skripsi, Departemen Teknik Kimia, Fakultas Teknik, Universitas Indonesia, Jakarta.

Nurseha, 2000, Isolasi dan Uji Aktivitas Bakteri Asidofilik Pengoksidasi Besi dan Sulfur dari Ekosistem Air Hitam, Tesis, Program Pasca Sarjana Institut Pertanian Bogor, Bogor.

Pradhan, N., Nathsarma, K.C., Rao, K.S., Sukla, L.B, Mishra, B.K., 2008, Heap Bioleaching of Chalcopyrite: A Review, Mineral Engineering, 21(5), 355-365 
Yusthinus T. Male dkk. / Indo. J. Chem. Res., 2019, 6(2), 101-106

Putro, B. I. K. E., 2008. Isolasi dan Karakterisasi Thiobacillus ferrooxidans dari Berbagai Jenis Tanah, Skripsi, Departemen Ilmu Tanah Dan Sumberdaya Lahan, Fakultas Pertanian, Institut Pertanian Bogor, Bogor.
Sudarsono, A.S., 2003, Pengantar Pengolahan dan Ekstraksi Biji Emas. Departemen Pertambangan ITB, Bandung. 